\title{
The Influence of Tourism Attributes and Promotion on the Consumer Image and Decision to Revisit Kintamani Ecotourism, Bangli Regency
}

\author{
Anak Agung Putu Agung ${ }^{1, *}$, Made Tamba ${ }^{1} \&$ I Gusti Ary Suryawathy ${ }^{1}$ \\ ${ }^{1}$ Economic Faculty, Universitas Mahasaraswati Denpasar, Denpasar, Indonesia \\ *Correspondence: Economic Faculty, Universitas Mahasaraswati Denpasar, Indonesia. Tel: 62-812-393-2480. \\ E-mail: putuagung56@yahoo.com
}

Received: April 25, 2015

doi:10.5430/mos.v2n3p72
Accepted: June 25, $2015 \quad$ Online Published: July 14, 2015

URL: http://dx.doi.org/10.5430/mos.v2n3p72

\begin{abstract}
The objectives of this research are (1) to analyze the influence of tourism attributes on consumer image and decision to revisit; (2) to analyze the influence of promotion on consumer image and decision to revisit; (3) to analyze the influence of consumer image on decision to revisit Kintamani Ecotourism, Bangli Regency. Data collected by distributing questionnaires on five point Likert scale. Data analyzed descriptively and inferentially. Confirmatory Factor Analysis reveals that Price was the most powerful indicator that influences Tourism Attributes with a loading factor value of 15.334; while Advertisement was the most powerful indicator that influences Promotion with a loading factor value of 28.319; while Consumer image was influenced dramatically by Comfortable Environment (24.082). Decision to Visit (13.745) was the most powerful indicator that influences Decision to Revisit. Partial Least Square Analysis portrays that t-statistic valued above 1.96 which means that all paths are significant. Path coefficient of Tourism Attributes (X1) to Consumer image (Y1) was 5.784; while Promotion (X2) to Consumer image (Y1) was 3.464. Path coefficient between Consumer Image and (Y1) and Decision to Revisit (Y2) was 7.059.
\end{abstract}

Keywords: Tourism attributes, Consumer image, Decision to revisit, Ecotourism, Promotion

\section{Introduction}

\subsection{Background}

Various international organizations, such as the World Bank and WTO, have acknowledged that tourism is an integral part of human life, especially regarding the social and economic activities. Previously, tourism was enjoyed by only a handful of people who are relatively rich in the early 20th century; but now, tourism has become a part of human rights.

In the last three decades, tourism sector in Bali has brought changes in the economic structure from primary sector domination to tertiary sector domination. In 1970, the contribution of primary sector amounted to59.07 per cent and tertiary sector 33.36 per cent. In 2010, there has been a significant change where the primary sector accounted for only21.37 per cent; while the tertiary sector accounts for 63.26 percent of gross domestic product of Bali. Of these contributions, 28.88 per cent was the contribution of trade, hotels and restaurants. Thus, tourism sector has been contributed most to the GDP of Bali. Tourism development is inseparable from the appeal of existing attractions, both natural and culture, tourism objects, as well as ecotourism. Ecotourism development should be encouraged in order to maintain tourism sustainability in Bali. The benchmark of ecotourism principles is a combination among sustainable ecology, tourists' satisfaction and alignments on local communities. A sustainable ecology is the primary condition in capturing all tourism development activities, with concerns on the socio-cultural ecology, nature and biological chemistry.

Previous researches revealed that many factors influenced tourist visit, for instance promotion, tourism attribute, consumer image, needs and lifestyle. Based on those research findings, many marketers became confuse in choosing which strategy should be applied in marketing a tourist destination. Similar problem also faced in Kintamani ecotourism. They have problems in formulating appropriate marketing strategies to increase the number of tourist visits. In fact, the number of tourist visits to Kintamani decreased, although Kintamani is a leading ecotourism in Bali. This downward trend indicates problems being faced by Kintamani, which can be identified from marketing 
factors such promotion, tourism attribute, characteristics of visitors, consumer image, attractiveness or combination of these factors. To answer this problems; it is very important to carry out a research on marketing strategies to increase the number of tourist visits to Kintamani ecotourism.

\subsection{Specific Aims}

The general purpose of this research is to design a model or marketing strategy to increase tourist visits to Kintamani ecotourism. Particularly, this research aimed to:

1. Analyze the influence of tourism attributes on consumer image and decision to revisit.

2. Analyze the influence of promotion on consumer image and decision to revisit.

3. Analyze the influence of consumer image on decision to revisit.

\subsection{Research Urgency}

Ecotourism development is becoming increasingly crucial and urgent as the development of tourism in Bali has now reached the stage where the antagonist of ecological destruction has begun to be felt by the society. According to Butler, this stage is known as maturity stage approaching to decline. Thus, the time has come for fundamental changes of tourism development from materiality paradigm with purely economic benchmarks to sustainable ecotourism development.

The increasing visitors have become an obsession of the ecotourism management. A proper marketing strategy can boost the number of the visitors up significantly. As a consequence, this can increase local government revenue which at the same time can drive up local economic growth.

\section{Structure}

\subsection{Theoretical Framework}

\subsubsection{Ecotourism Concept}

According to the International Ecotourism Society (2006), ecotourism defines as travel activities that packed professionally, trained and contain education element as a business sector which consider the cultural heritage, participation and well-being of the local population as well as the efforts of conservation of natural resources and the environment. Susilawati (2008) suggested that ecotourism development in response to an effort to minimize the risks or negative impacts of tourism industry.

The potential implementation of good ecotourism brings positive impact for the environment as this can be a source to finance resource conservation, increase the economic value of resources and socio-cultural as well as empowering local communities

\subsubsection{Tourism Attributes}

According to Tjiptono (1997), product attribute is crucial elements accounted by consumers, which acts as the based for purchase decision. Gartner (1993) revealed that tourist visits in Korea were motivated by tangible tourism attribute, such as shopping; and intangibles tourism attribute, such as local culture. Law (1995) suggested that there are two factors that contribute to the attractiveness of tourist destination; (1) primary factor which includes climate, environment, culture, traditional architectures and natural resources; (2) secondary factor which includes tangible and intangible assets which is developed by tourists such as hotel, catering and other activities and attractions.

\subsubsection{Promotion}

Promotion is a kind of communication that provides a convincing explanation to prospective customers about goods and services (Simamora, 2004). According to Payne (1993) promotion is a tool that can be used by service organizations to communicate with target market. Communication is the process of sharing ideas, information or feelings of the audience. Promotional purpose is to inform, persuade and remind the existence of a product to consumers. Stanton (1990) suggested that there are four factors that influence promotion; they are the availability of promotion funds, market condition, product characteristics and product cycle. According to Simamora (2004), factors that influence promotion are marketer, target market, product and environment.

\subsubsection{Environment Characteristics}

According to Kotler (2003), consumers' behavior in buying a product or service is determined by marketing stimuli and their individual characteristics. He further explained that consumers' characteristics include culture, social, personal and psychology. Cultural factors have a wide spread and profound influence on buying behavior, such as 
values, family behavior, preferences, religion, nationality, taste and geographic area. Social factors that influence consumers' behavior are reference groups, family, roles and social status. One's reference group consisted of all groups that have direct or indirect influence on someone's behavior. This group is a place where people interact and consists of primary and secondary groups. Primary group tends to be informal, such as family, friends, neighbors and co-workers; while the secondary group is more formal, such as religious groups, professional and trade associations. Personal factors that influence consumers' behavior are age, life cycle, occupation, economy condition and personal concept of the consumers.

\subsubsection{Ecotourism Characteristics in Indonesia}

Tourism business is a service business that aims to provide benefits for tourists, local residents and local governments. Tourism can provide the standard of life of local residents through the economic benefits derived from tourist destinations. For local government, tourism business can contribute to the local revenue. Tourism business as reflected in Article1 paragraph 5 of Law No.9 year 1990 defines as activities that aim at providing tourism services, objects and attractions, business tourism facilities and other businesses related to that field. This research focused on tourism business. According to Marpaung (2002), tourism attraction classified into scenery, beach, park, mountainous, flora and fauna and virgin island. Fandeli (1995) suggested that there are two factors that influence tourism: (1) driving factors which include getaway from daily routine, polluted environment, traffic and hustle and bustle in the city; (2) attracting factors which relate to tourism attraction, for instance well known tourism.

\subsubsection{Consumer Image}

Image defines as a concept of something (Sutisna, 2003). According to Bennet (1995), image is consumers' perception of a product, institution, brand, company or person that suited or unsuited with the reality. Kotler (2003) defines image as an array of beliefs, images and impressions of a person to an object. Simamora (2002) suggested there are two approaches to measure consumer image: (1) unstructured approach that is reflex image based on someone's perception; (2) structured image that is a clearly explained dimension and respondents filled up the dimension being asked. Andrew et al. (2000) suggested that image relates to people's perceptions about tourist destinations and is influenced by the growth in tourist destinations or physical resources.

\subsubsection{Purchased Decision}

According to Hawkins et al. (1988), consumer behavior is the study of individual, group or organization and the process they carried out to select, secure, use and define the product, service, experience or ideas to satisfy their needs. Factors that influence purchased decision are (1) internal factors which include perception, motivation, behavior, emotion, memory and personality; and (2) external factors which include culture, social cluster, family, group references, marketing, service, facility and promotion. Eagle et al. (1995) defined consumer behavior as immediate steps in acquiring and consuming products and services, including the preceding and the after processes. Following were steps taken by consumers in deciding to purchase starting from there is awareness of the needs, looking for information, evaluating purchase alternatives, purchase, consume, final results in the form of satisfaction or dissatisfaction.

\subsubsection{Previous Researches}

Tamba et al. (2011) carried out research on Kintamani Ecotourism Management and revealed that: (1) 77 per cent of the communities agreed on Kintamani as ecotourism; (2) 91 per cent of the communities supported Kintamani as ecotourism; (3) 91 per cent of the tourist's perceptions were positive toward Kintamani ecotourism. Suggestions for Kintamani ecotourism are as follow:

1. Souvenir hawkers should be disciplined for not disturbing tourists' comfortably in enjoying tourism products.

2. The existence of flora and fauna should be preserved.

3. The need to create more tourism packages, for instance equestrian, trekking and cycling, hiking, fishing, parasailing and dance performance.

4. The availability local guide who knows comprehensively about the existence of Kintamani ecotourism.

5. More promotion on Kintamani ecotourism should be carried out, for instance through website.

Based on the problem analysis and its potency which is combined with perception, behavior, knowledge, community's supports and tourist's perceptions and expectations with regards to Tri Hita Karana concept; thus it is recommended that the management of Kintamani ecotourism should be based on traditional village system. 


\subsection{Research Method}

Population in this research is both local and international tourists who visit Kintamani. The sample is tourists who visit Kintamani on July 2014. Data collected by distributing questionnaires on five point Likert scale. Data analyzed descriptively and inferentially. Descriptive analysis is used to describe the respondents and variables; while partial least square analysis is used to discern the relationship between variables. Variable and indicators used in this study shown in Table 1.

Table 1. Research Variables and Indicators

\begin{tabular}{lllc}
\hline No. & Variable & Indicator & Notation \\
\hline 1 & Tourism attributes (X1) & Attraction & $\mathrm{X} 1.1$ \\
& & Easy to reach & $\mathrm{X} 1.2$ \\
& & Price & $\mathrm{X} 1.3$ \\
& & Accommodation & $\mathrm{X} 1.4$ \\
& & Souvenirs & $\mathrm{X} 2.5$ \\
\hline 2 & Promotion (X2) & Publication & $\mathrm{X} 2.2$ \\
& & Word of Mouth & $\mathrm{X} 2.3$ \\
& & Advertisement & $\mathrm{X} 2.4$ \\
\hline 3 & Consumer Image (Y1) & e-commerce & $\mathrm{Y} 1.1$ \\
& & Comfortable environment & $\mathrm{Y} 1.2$ \\
& & Cool and fresh & $\mathrm{Y} 1.3$ \\
& & Fun & $\mathrm{Y} 1.4$ \\
& & Clean & $\mathrm{Y} 1.5$ \\
\hline 4 & Decision to revisit (Y2) & Safety & $\mathrm{Y} 2.1$ \\
& & Needs & $\mathrm{Y} 2.2$ \\
& & Looking for information & Y2.3 \\
& & Decision to visit & Y2.4 \\
\hline
\end{tabular}

\section{Results and Discussions}

\subsection{Descriptive Analysis}

Descriptive analysis is carried out to discern tourist's perceptions on tourism attributes, promotion, consumer images and decision to revisit Kintamani ecotourism.

a. Tourism attributes

The percentage of tourist's perception on tourism attributes of Kintamani as ecotourism is shown in Table 2.

Table 2. Tourist's Perception on Tourism Attributes

\begin{tabular}{lcc}
\hline Assessment Category & No. of Tourists & Percentage \\
\hline Worst & 0 & 0 \\
Bad & 2 & 5 \\
Fair & 17 & 42.5 \\
Good & 19 & 47.5 \\
Well & 2 & 5 \\
Total & 40 & 100 \\
\hline
\end{tabular}

Source: data processed (2014)

The finding shows that 47.5 per cent of the respondents viewed that Kintamani's attributes which consist of attraction, easy to reach, price, accommodation and souvenirs was good, while 42.5 per cent viewed fair. The assessment category of bad and well has the same percentage that was 5 per cent.

b. Promotion

The percentage of tourist's perception on the promotion of Kintamani as ecotourism is shown in Table 3 . 
Table 3. Tourist's Perception on Promotion

\begin{tabular}{lcc}
\hline Assessment Category & No. of Tourists & Percentage \\
\hline Worst & 1 & 2.5 \\
Bad & 2 & 5 \\
Fair & 8 & 20 \\
Good & 25 & 62.5 \\
Well & 4 & 10 \\
Total & 40 & 100 \\
\hline
\end{tabular}

Source: data processed (2014)

The finding reveals that the highest percentage (62.5 per cent) of respondents' perception was good; followed by fair (20 per cent). Only 2.5 per cent of the respondents viewed that the promotion of Kintamani as ecotourism was worst.

c. Consumer Image

The percentage of tourist's perception on consumer image is shown in Table 4.

Table 4. Tourists' Perception on Consumer Image

\begin{tabular}{lcc}
\hline Assessment Category & No. of Tourists & Percentage \\
\hline Worst & 1 & 2.5 \\
Bad & 0 & 0 \\
Fair & 7 & 17.5 \\
Good & 25 & 62.5 \\
Well & 7 & 17.5 \\
Total & 40 & 100 \\
\hline
\end{tabular}

Source: data processed (2014)

The finding portrays that 62.5 per cent of the respondents gave good perception on consumer image, which consists of comfortable environment, cool and fresh, fun, clean and safety; and 17.5 percent viewed well. Only 2.5 per cent of the respondents viewed worst on consumer image.

d. Decision to revisit

The percentage of tourist's perception on decision to revisit Kintamani ecotourism is shown in Table 5.

Table 5. Tourist's Perception on Decision to Revisit

\begin{tabular}{lcc}
\hline Assessment Category & No. of Tourists & Percentage \\
\hline Worst & 1 & 2.5 \\
Bad & 0 & 0 \\
Fair & 9 & 22.5 \\
Good & 25 & 62.5 \\
Well & 5 & 12.5 \\
Total & 40 & 100 \\
\hline
\end{tabular}

Source: data processed (2014)

Based on Table 5, 62.5 per cent of the respondents gave good perception on the decision to revisit Kintamani, which consist of needs, looking for information, decision to visit and post visit evaluation. 22.5 per cent of the respondents viewed fair and 12.5 per cent viewed well.

\subsection{Confirmatory Factor Analysis}

Loading factor of confirmation factor analysis can be used to determine the most powerful factor that influences latent variable. Confirmatory factor analysis result is shown in Figure 1.

Confirmatory analysis result for tourism attributes variable is shown in Table 6. 
Table 6. Confirmatory Result of Tourism Attributes

\begin{tabular}{llc}
\hline & Indicator & Loading Factor \\
\hline X1.1 & Attraction & 3.914 \\
X1.2 & Easy to reach & 1.849 \\
X1.3 & Price & 15.334 \\
X1.4 & Accommodation & 7.313 \\
X1.5 & Souvenirs & 1.668 \\
\hline
\end{tabular}

Source: data processed (2014)

Table 6 indicates that price was the most powerful indicator that influences tourism attributes with a loading factor value of 15.334; followed by accommodation (7.313), attraction (3.914) and easy to reach (1.849). The least powerful indicator was souvenirs with a loading factor value of 1.668 .

Confirmatory analysis result for promotion variable is shown in Table 7.

Table 7. Confirmatory Result for Promotion

\begin{tabular}{llc}
\hline & Indicator & Loading Factor \\
\hline X2.1 & Publication & 16.693 \\
X2.2 & Word of mouth & 9.742 \\
X2.3 & Advertisement & 28.319 \\
X2.4 & e-commerce & 3.197 \\
\hline
\end{tabular}

Source: data processed (2014)

Table 7 portrays that advertisement was the most powerful indicator that influences promotion with a loading factor value of 28.319; followed by publication (16.693) and word of mouth (9.742). The least powerful indicator was e-commerce with a loading factor value of 3.197 .

Confirmatory analysis result for consumer image variable is shown in Table 8.

Table 8. Confirmatory Result for Consumer Image

\begin{tabular}{llc}
\hline & Indicator & Loading Factor \\
\hline Y1.1 & Comfortable environment & 24.082 \\
Y1.2 & Cool and fresh & 5.750 \\
Y1.3 & Fun & 6.979 \\
Y1.4 & Clean & 5.584 \\
Y1.5 & Save & 4.217 \\
\hline
\end{tabular}

Source: data processed (2014)

Table 8 indicates that comfortable environment was the most powerful indicator that influences consumer image with a loading factor value of 24.082; followed by fun (6.979) and coolness and freshness (5.750). The least powerful indicator was safety with a loading factor value of 4.217.

Confirmatory analysis result for decision to revisit variable is shown in Table 9.

Table 9. Confirmatory Result for Decision to Revisit

\begin{tabular}{llc}
\hline & Indicator & Loading Factor \\
\hline Y2.1 & Consciousness of the needs & 10.929 \\
Y2.2 & Looking for information & 9.117 \\
Y2.3 & Decision to visit & 13.745 \\
Y2.4 & Post visit evaluation & 8.662 \\
\hline
\end{tabular}

Source: data processed (2014) 
Table 9 portrays that decision to visit was the most powerful indicator that influences decision to revisit with a loading factor value of 13.745; followed by needs (10.929) and looking for information (9.117). The least powerful indicator was post visit evaluation with a loading factor value of 8.662 .

\subsection{Path Coefficient Analysis}

Based on Partial Least Square diagram (Figure 1), the estimation result shows that t-statistic valued above 1.96 which means that all paths are significant. Path coefficient of Tourism Attributes (X1) to Consumer Image (Y1) was 5.784; while Promotion (X2) to Consumer Image (Y1) was 3.464. Path coefficient between Consumer Image and (Y1) and Decision to Revisit (Y2) was 7.059.

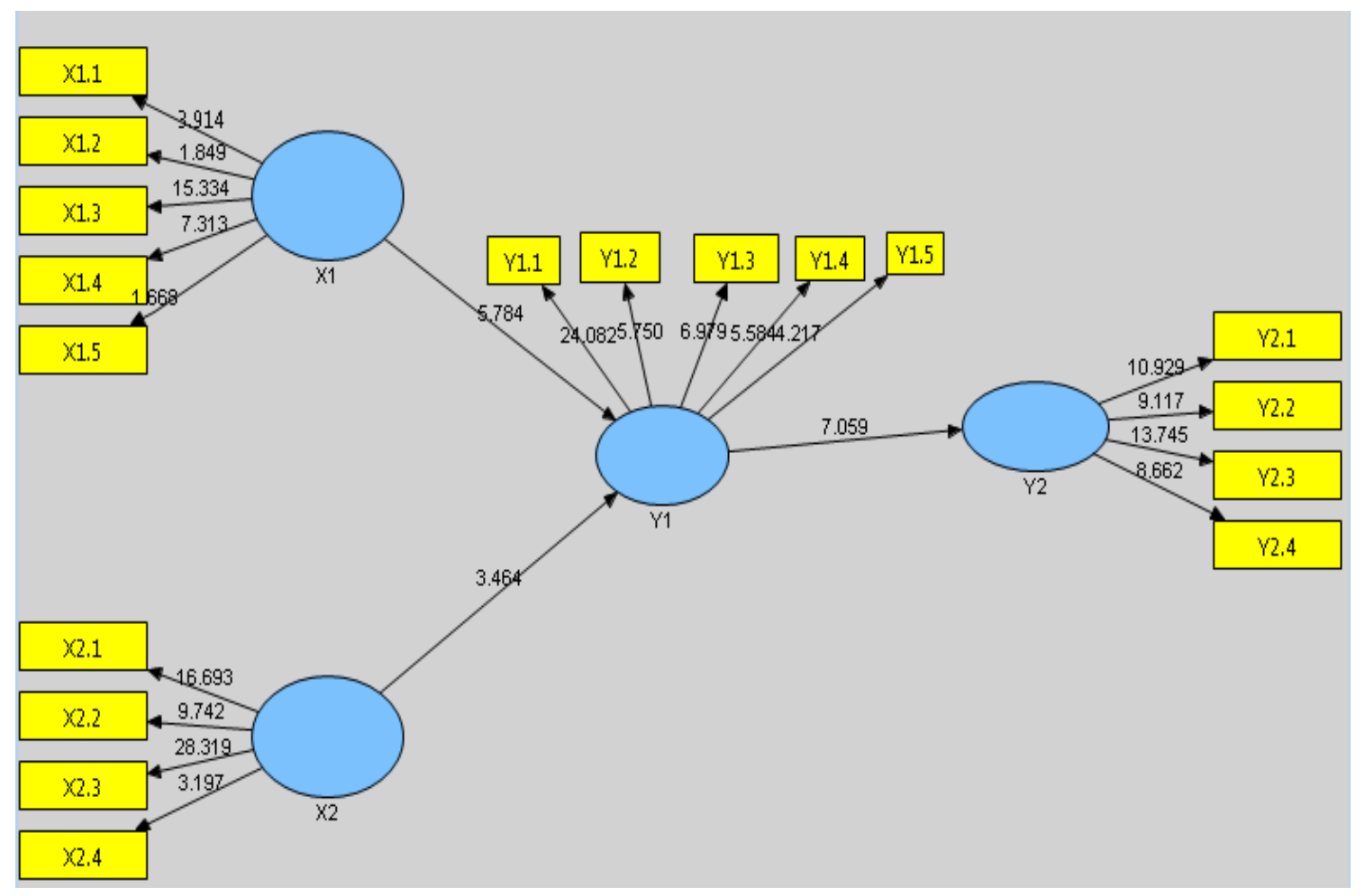

Figure 1. Partial Least Square Diagram

\section{Conclusion}

Based on the research findings, conclusion can be drawn that most of the tourists claimed that Kintamani ecotourism attributes were attracting. Promotion needs to be boost up through publication, advertisement, e-commerce and word of mouth. Meanwhile, individual characteristics are suited to foster tourist visits. Consumer image on Kintamani was good, except for safety, cleanliness, souvenirs merchants' service and traffic. Therefore, it is suggested that both Batur Pekraman Village and Bangli Regency can make more effective promotion in form of publication, advertisement, word of mouth and e-commerce and pay more attention on consumer image particularly on safety, cleanliness, souvenirs merchants' service and traffic. Appropriate policies on both promotion and consumer image can boost tourist visits to Kintamani ecotourism.

\section{References}

Ahmed, Z.U. (1996). The Need for The Identification of The Constituents of a Destination's Tourist Image: A Promotion Segmentation Perspective. Journal of Professional Services Marketing, 14(1), 23-34. http://dx.doi.org/10.1300/J090v14n01_04

Andreu, Luisa, J. Enrique Bigne \& Chris Cooper. (2000). Projected and Perceived Image of Spain as Tourist Destination for British Travellers. Journal of Travel \& Tourism Marketing, 9(4), 47-67. http://dx.doi.org/10.1300/J073v09n04_03 
Baksir, Abdurrachman., Fredinan Yulianda. T.F., Djamar Lumbatu \& Rahardjo M.F. (2009). Model Pengelolaan Ekowisata Pulau-pulau Kecil Berkelanjutan di Kecamatan Morotai Selatan dan Morotai Selatan Barat Kabupaten Halmahera Utara, Propinsi Maluku Utara. Jurnal Ilmu Kelautan dan Perikanan, 19(1), 1-8.

Bennet, P.D. (1995). Dictionary of Marketing Terms, American Marketing Association. Chicago: NTC Bussiness Books.

Chen, C-C. (2004). Resident Perception of The Effect of Tourism: A Case Study of The Crystal Basin Recreation Area, California. e-Review of Tourism Research, 37(3), 256-66.

Gartner, W.C. (1993). Image Foundation Process. Journal of Travel \& Tourism Marketing, 2(3), 191-215.

Gronroos, C. (1990). Service Management and Marketing: Managing The Moment of Truth in Service Competition. Lexington Blooks. Maxwell MacMillan International Edition.

Hawkins, Del I., Best R.J., \& Coney K.A. (1998). Consumer Behavior, Building Marketing Strategy(7th Edition). McGraw-Hill.

Kotler, P. (2003). Dasar-dasar Pemasaran. Edisi kesembilan. Jilid 1. Terjemahan Tim Markplus. Jakarta: PT Indeks Kelompok Gramedia.

Laws, E. (1995). Tourist Destination Management: Issues, Analysis and Policies. London: Routledge.

Marpaung, H. (2002). Pengetahuan Pariwisata. Edisi Revisi. Bandung: Penerbit ALFABETA.

Susilawati. (2008). Pengembangan Ekowisata Sebagai Salah Satu Upaya Pemberdayaan Sosial, Budaya Dan Ekonomi di Masyarakat. Jurnal Pendidikan Geografi, 8(1).

Sutisna. (2003). Perilaku Konsumen dan Komunikasi Pemasaran. Bandung: PT Remaja Rosdakarya Offset.

Tamba dan Setia Sapta. (2011). Sistem Pengelolaan Ekowisata Kintamani untuk Mendukung Cagar Budaya. Kementrian Pariwisata Republik Indonesia.

The International Ecotourism Society. (2006). Fact Sheet: Global Ecotourism. Updated Edition, September 2006. 